\title{
Article \\ Geographical Distribution and Genetic Diversity of the Banana Fusarium Wilt Fungus in Laos and Vietnam
}

\author{
Khonesavanh Chittarath ${ }^{1,+}$, Chung Huy Nguyen ${ }^{2,+}$, Wendy C. Bailey ${ }^{3}$, Si-Jun Zheng ${ }^{4,5}{ }^{\oplus}$, Diane Mostert ${ }^{3}{ }^{\oplus}$, \\ Altus Viljoen ${ }^{3}$, Anthony Fredrick Tazuba ${ }^{6}$, Walter Ocimati ${ }^{6} \mathbb{D}$, Elizabeth Kearsley ${ }^{7}{ }^{\mathbb{D}}$, Trần Yến Chi ${ }^{8}$, \\ Nguyen Thi Tho ${ }^{2}$, Nguyen Tien Hung ${ }^{2}$, Miguel Dita ${ }^{9} \mathbb{D}$, Trushar Shah ${ }^{10} \mathbb{D}$, Margaret Karanja ${ }^{10}$, \\ George Mahuku ${ }^{11}$ and Guy Blomme ${ }^{12, *(D)}$
}

\section{check for}

updates

Citation: Chittarath, K.; Nguyen,

C.H.; Bailey, W.C.; Zheng, S.-J.;

Mostert, D.; Viljoen, A.; Tazuba, A.F.; Ocimati, W.; Kearsley, E.; Chi, T.Y.; et al. Geographical Distribution and Genetic Diversity of the Banana

Fusarium Wilt Fungus in Laos and Vietnam. J. Fungi 2022, 8, 46. https:// doi.org/10.3390/jof8010046

Academic Editors: Jeffrey J. Coleman and David S. Perlin

Received: 31 October 2021

Accepted: 29 December 2021

Published: 2 January 2022

Publisher's Note: MDPI stays neutral with regard to jurisdictional claims in published maps and institutional affiliations.

Copyright: (C) 2022 by the authors. Licensee MDPI, Basel, Switzerland. This article is an open access article distributed under the terms and conditions of the Creative Commons Attribution (CC BY) license (https:// creativecommons.org/licenses/by/ $4.0 /)$.
1 Plant Protection Center, Department of Agriculture, Ministry of Agriculture and Forestry, Vientiane 01001, Laos; chittarhat_2005@yahoo.com

2 Plant Protection Research Institute, Duc Thang Commune, Bac Tu Liem District, Hanoi 119000, Vietnam; hchungvasi@yahoo.com (C.H.N.); ntho57.ppri@gmail.com (N.T.T.); hungnguyen1218@gmail.com (N.T.H.)

3 Department of Plant Pathology, Stellenbosch University, Stellenbosch 7602, South Africa; wbailey@sun.ac.za (W.C.B.); diane@sun.ac.za (D.M.); altus@sun.ac.za (A.V.)

4 Yunnan Key Laboratory of Green Prevention and Control of Agricultural Transboundary Pests, Agricultural Environment and Resources Institute, Yunnan Academy of Agricultural Sciences, Kunming 650205, China; s.zheng@cgiar.org

5 The Alliance of Bioversity and CIAT, Kunming 650205, China

6 The Alliance of Bioversity and CIAT, Kampala P.O. Box 24384, Uganda; tazubatony@gmail.com (A.F.T.); w.ocimati@cgiar.org (W.O.)

7 BlueGreen Labs, 9120 Melsele, Belgium; kearsleyelizabeth@gmail.com

8 Plant Protection Department, 149 Ho Dac Di, Dong Da, Hanoi 115000, Vietnam; yenchitran84@gmail.com

9 The Alliance of Bioversity and CIAT, Cali-Palmira CP 763537, Colombia; m.dita@cgiar.org

10 IITA, Nairobi P.O. Box 30709-00100, Kenya; tm.shah@cgiar.org (T.S.); m.karanja@cgiar.org (M.K.)

11 IITA, Kampala P.O. Box 7878, Uganda; g.mahuku@cgiar.org

12 The Alliance of Bioversity and CIAT, Addis Ababa P.O. Box 5689, Ethiopia

* Correspondence: G.Blomme@cgiar.org

+ These authors made an equal contribution to the paper and share first authorship.

Abstract: Fusarium wilt, caused by the fungus Fusarium oxysporum f. sp. cubense (Foc), poses a major threat to global banana production. The tropical race 4 (TR4) variant of Foc is a highly virulent form with a large host range, and severely affects Cavendish bananas. Foc TR4 was recently observed within the Greater Mekong Subregion, after Chinese private companies expanded Cavendish production to the region. In this study, extensive surveys conducted across Laos and Vietnam show that Foc TR4 is still mainly constricted to the northern regions of these countries and is limited to Cavendish cultivation settings. In Laos, Foc TR4 is associated with large-scale Cavendish plantations owned by or involved with Chinese companies through which infected planting material could have been imported. In Vietnam, mostly small-holder Cavendish farmers and backyard gardens were affected by Foc TR4. In Vietnam, no direct link is found with Chinese growers, and it is expected the pathogen mainly spreads through local and regional movement of infected planting materials. Foc TR4 was not recorded on banana cultivars other than Cavendish. The extensively cultivated 'Pisang Awak' cultivar was solely infected by VCGs belonging to Foc race 1 and 2, with a high occurrence of VCG 0123 across Laos, and of VCG 0124/5 in Vietnam. Substantial diversity of Foc VCGs was recorded (VCGs 0123, 0124/5, 01218 and 01221) from northern to southern regions in both countries, suggesting that Fusarium wilt is well established in the region. Interviews with farmers indicated that the local knowledge of Fusarium wilt epidemiology and options for disease management was limited. Clear communication efforts on disease epidemiology and management with emphasis on biosecurity practices need to be improved in order to prevent further spread of Foc TR4 to mixed variety smallholder settings.

Keywords: Cavendish; field survey; Fusarium TR4; Greater Mekong Subregion; 'Pisang Awak' 


\section{Introduction}

Fusarium wilt is a major disease of banana (Musa spp.) found in most banana-growing countries [1-4]. The disease is caused by a soil-borne ascomycete fungus, Fusarium oxysporum f. sp. cubense (Foc), which evolved with its host in Southeast Asia. Foc infects the roots of banana, then blocks the vascular system of the plant, thereby causing wilting and eventual death $[5,6]$. The fungus reproduces strictly asexually and can survive as chlamydospores in infested banana fields for up to 30 years. It also survives as an asymptomatic endophyte in alternative host plants such as weeds [7-11]. Foc is spread locally and regionally with infected planting material and infested soil and water [11].

Foc is a highly diverse pathogen that comprises different evolutionary lineages. The fungus is classified into three physiological races based on its pathogenicity to differential host cultivars, with Foc race 1 (R1) affecting 'Gros Michel' (AAA), 'Lady Finger' (AAB) and 'Pisang Awak' (ABB) bananas; Foc race 2 (R2) affecting 'Bluggoe' (ABB) and closely related $\mathrm{ABB}$ clones; and Foc race 4 (R4) affecting the 'Cavendish' banana subgroup (AAA) as well as most cultivars susceptible to Foc $R 1$ and $R 2[3,6,12,13]$. However, the race structure is often confusing and inaccurate in delineating Foc strains. To improve the identification of Foc strains, heterokaryon formation between Foc isolates is used to further divide the fungus into 24 vegetative compatibility groups (VCGs) [12,14,15].

Foc R4 has been divided into 'subtropical' race 4 (SR4) and 'tropical' race 4 (TR4) strains, based on their ability to cause disease to Cavendish bananas under different environmental conditions [16,17]. Foc SR4 strain infects Cavendish bananas in the subtropics only, whilst Foc TR4 affects Cavendish in both the tropics and subtropics [12,18]. Phylogenetically, Foc SR4 strains consist of VCGs 0120/15, 0122, 0126, 0129/11, 01210 and 01219, whereas Foc TR4 includes the VCG complex 01213/16 and 0121 [4,19,20].

Foc TR4 is considered to be the most damaging form of Foc due to its wide host range and severe effect to Cavendish bananas, which constitute about $50 \%$ of all bananas produced globally [21]. The fungus was initially restricted to Southeast Asia and Australia until approximately 2012 [9,22-25], whereafter it has been detected in the Middle East [10,26,27], Mozambique and Mayotte in Africa [28,29], and Colombia and Peru in Latin America [30,31]. Foc TR4 also spread to new countries in Asia, most likely from China [23]. Since 2018 the fungus was reported in Laos [23,32], Vietnam [23,33], Myanmar and Cambodia [23] and Thailand [34]. These detections occurred after Chinese private companies expanded Cavendish production in the Greater Mekong Subregion (Laos, Vietnam, Myanmar and Cambodia) following a decline in banana production in southern China due to Fusarium wilt [23]. The private companies frequently transport planting materials and relocate farm equipment from infested areas in China into the Greater Mekong Subregion countries, thereby increasing the risks of disseminating Foc TR4 [10].

In this study, the distribution and diversity of Foc in banana fields in Laos and Vietnam were investigated through field surveys. Laos and Vietnam are of specific interest for Fusarium wilt surveys, since banana production in both countries has increased significantly from 1.6 to 2.2 Mt in northern and southern Vietnam, and from 0.18 to $1.06 \mathrm{Mt}$ in Laos, over the past decade [21]. During this period, banana cultivation has also shifted from local dessert bananas towards the production of Cavendish bananas, which currently represents $80 \%$ of bananas in Vietnam (Personal communication, 2021, Deputy director of Fruit and Vegetable Research Institute, Vietnam) and 85\% of all bananas grown in Laos [35]. The objectives of the surveys were to (a) collect, conserve, and characterize Foc isolates from Laos and Vietnam, (b) assess the genetic diversity and distribution of Musa varieties affected by banana Fusarium wilt (TR4 and other races), and (c) determine the status and extent of Foc TR4 infestation in Laos and Vietnam for future mitigation and disease prevention.

\section{Materials and Methods}

\subsection{Study Area and Field Surveys}

Two field surveys were organized across Laos and Vietnam to determine the presence of banana Fusarium wilt. The first survey was performed in 12 provinces in Vietnam 
between September 2018 and February 2019, and in 12 provinces in Laos between September 2018 and October 2019 (Figure 1). These surveys solely focused on Cavendish banana fields and cultivation zones. The Cavendish cultivar was selected because of its extreme susceptibility to Foc TR4, and because Foc TR4 was anticipated to have been introduced with infected planting materials and imported machinery by Chinese Cavendish bananaproducing companies. A second survey was performed between September and November 2020. This survey also included all banana cultivars and small-holder farms that could have been infected through local trade and contact with Foc TR4-affected Cavendish farms. Eight provinces in Laos and two provinces in Vietnam that were part of the 2018 survey were again visited, as well as an additional four and nine provinces in Laos and Vietnam, respectively (Figure 1).

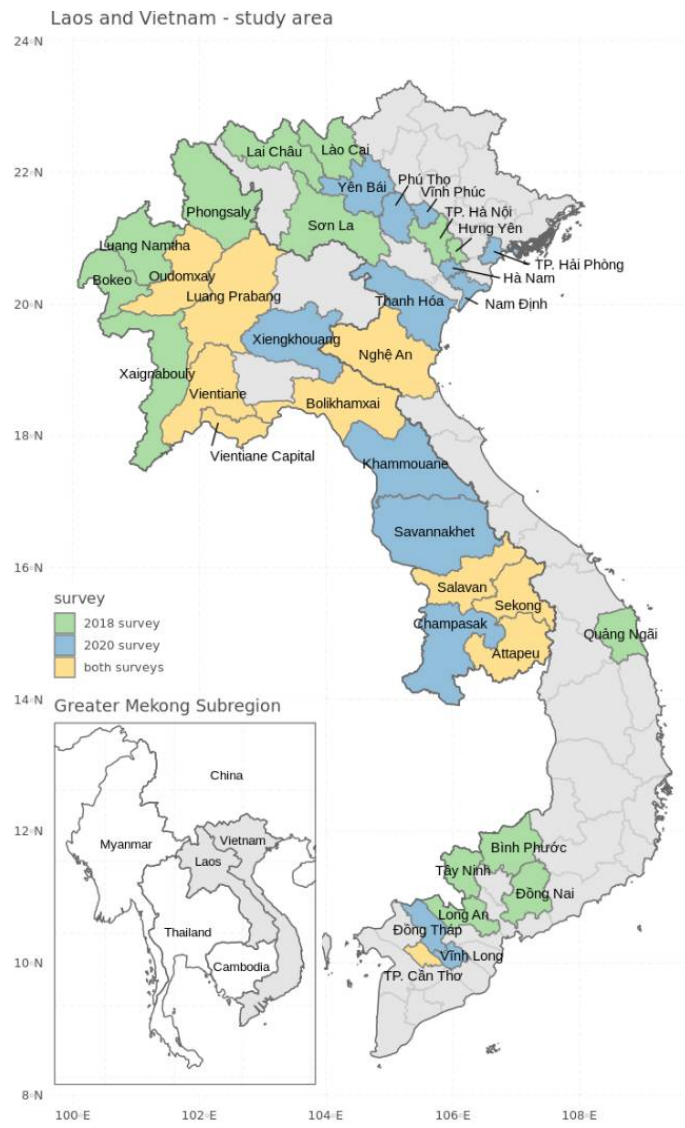

Figure 1. Laos and Vietnam survey area. Provinces that were surveyed in 2018 are indicated in green, and the provinces that were surveyed in 2020 are indicated in blue. The provinces that were surveyed during both years are indicated in yellow.

Field surveys and sample collection activities were carried out on large banana plantations, smallholder farms and backyard gardens where symptoms reminiscent of Fusarium wilt were observed. In the 2018 survey, one to five districts per province were selected for sampling, with a total of 27 districts, 46 villages and 155 fields in Laos, and 40 districts, 71 villages and 147 fields in Vietnam (Table 1). One to five symptomatic banana plants were sampled in each field, depending on the number of symptomatic plants. The 2020 survey covered 27 districts, 96 villages and 120 fields in Laos, and 30 districts, 62 villages and 85 fields in Vietnam (Table 2). During this survey, one to three symptomatic banana mats were sampled per field. During both surveys, sampling consisted of the collection of banana pseudostem tissues from banana plants that showed characteristic Foc symptoms of leaf yellowing as described by Viljoen et al. [36]. Field sample collection data were collated into spread sheets using the Open Data Kit tool [37]. These data were subsequently curated 
and imported into the ONA platform (https: / company.ona.io/, accessed on 3 September 2021). This platform has been used to integrate and share the data collected by the different teams onto a common platform. The sample collection data for the 2018 and 2020 surveys have been combined and are available for download and visualization at the following link https: / / ona.io/seedtracker/149457/618308\#/table, accessed on 3 September 2021. The field level detailed survey data for the 2020 survey for both Laos and Vietnam, respectively, are available at the following links https://ona.io/seedtracker/149457/602284\#/table, accessed on 3 September 2021 and https://ona.io/seedtracker/149457/585678\#/table, accessed on 3 September 2021. Post-processing was performed using R version 3.6.3 [38].

During the 2020 survey, farmers were also interviewed about the presence of Fusarium wilt in their banana fields and backyard gardens, the constraints this disease and other biotic factors have caused to their banana production and which disease mitigation and control measures were applied. Additional questions were asked about their overall knowledge on fusarium wilt, including how it spreads, how it affects the banana plant and overall management.

Table 1. Overview of the 2018 survey. The number of districts, villages and fields are indicated for each province surveyed. The number of fields in which Fusarium oxysporum f. sp. cubense TR4 was positively identified are indicated. Foc TR4 was confirmed using a TR4-specific PCR primer [39].

\begin{tabular}{|c|c|c|c|c|c|c|c|}
\hline Country & Macro-Region & Region & Province & Districts & Villages & Fields & $\begin{array}{l}\text { Fields TR4 } \\
\text { Confirmed }\end{array}$ \\
\hline \multirow{13}{*}{ Vietnam } & \multirow{5}{*}{$\begin{array}{l}\text { Northern } \\
\text { Vietnam }\end{array}$} & \multirow{3}{*}{ North West } & Lào Cai & 3 & 4 & 10 & 8 \\
\hline & & & Lai Châu & 2 & 3 & 7 & 1 \\
\hline & & & Sơn La & 5 & 8 & 15 & 0 \\
\hline & & \multirow{2}{*}{ Red River Delta } & Hà Nội & 4 & 5 & 16 & 8 \\
\hline & & & Hưng Yên & 3 & 5 & 11 & 4 \\
\hline & Central & North Central & * Nghệ An & 3 & 10 & 22 & 0 \\
\hline & Vietnam & South Central & Quảng Ngãi & 3 & 7 & 14 & 0 \\
\hline & \multirow{5}{*}{$\begin{array}{l}\text { Southern } \\
\text { Vietnam }\end{array}$} & \multirow{3}{*}{ South East } & Bình Phước & 2 & 4 & 6 & 0 \\
\hline & & & Đồng Nai & 3 & 4 & 10 & 0 \\
\hline & & & Tây Ninh & 5 & 8 & 12 & 1 \\
\hline & & \multirow{2}{*}{ Mekong River Delta } & Cần Thơ & 3 & 5 & 13 & 0 \\
\hline & & & Long An & 4 & 8 & 11 & 1 \\
\hline & Total & & & 40 & 71 & 147 & 23 \\
\hline \multirow{13}{*}{ Laos } & \multirow{6}{*}{ Northern Laos } & \multirow{6}{*}{ North West } & Bokeo & 2 & 6 & 14 & 10 \\
\hline & & & Luang Namtha & 2 & 4 & 17 & 17 \\
\hline & & & Luang Prabang & 3 & 6 & 20 & 6 \\
\hline & & & Oudomxay & 3 & 5 & 10 & 6 \\
\hline & & & Phongsaly & 3 & 4 & 10 & 0 \\
\hline & & & Xaignabouly & 2 & 2 & 10 & 7 \\
\hline & \multirow{3}{*}{ Central Laos } & \multirow{3}{*}{ Central } & Vientiane Capital & 3 & 5 & 10 & 2 \\
\hline & & & Vientiane & 3 & 5 & 22 & 13 \\
\hline & & & Bolikhamxai & 1 & 3 & 6 & 0 \\
\hline & \multirow{3}{*}{ Southern Laos } & \multirow{3}{*}{ South East } & Attapeu & 2 & 3 & 17 & 0 \\
\hline & & & Salavan & 2 & 2 & 11 & 0 \\
\hline & & & Sekong & 1 & 1 & 8 & 0 \\
\hline & Total & & & 27 & 46 & 155 & 61 \\
\hline
\end{tabular}

* Provinces indicated in bold are surveyed in both the 2018 and 2020 surveys. 
Table 2. Survey overview of the 2020 survey. The number of districts, villages and fields are indicated for each province surveyed. The number of fields in which Fusarium oxysporum f. sp. cubense (Foc) TR4 and Foc R1/R2 were positively identified are indicated. Foc TR4 and Foc R1/R2 were confirmed using a Foc TR4 or Foc R1/R2-specific PCR primers and Vegetative Compatibility Groups.

\begin{tabular}{|c|c|c|c|c|c|c|c|c|}
\hline Country & $\begin{array}{l}\text { Macro- } \\
\text { Region }\end{array}$ & Region & Province & Districts & Villages & Fields & $\begin{array}{l}\text { Fields TR4 } \\
\text { Confirmed }\end{array}$ & $\begin{array}{c}\text { Fields } \\
\text { R1/R2 } \\
\text { Confirmed }\end{array}$ \\
\hline \multirow{12}{*}{ Vietnam } & \multirow{6}{*}{$\begin{array}{l}\text { Northern } \\
\text { Vietnam }\end{array}$} & North West & Yên Bái & 3 & 7 & 10 & 0 & 5 \\
\hline & & North East & Phú Thọ & 4 & 7 & 11 & 3 & 5 \\
\hline & & \multirow{4}{*}{$\begin{array}{l}\text { Red River } \\
\text { Delta }\end{array}$} & Hà Nam & 5 & 9 & 10 & 0 & 3 \\
\hline & & & Hải Phòng & 2 & 7 & 10 & 1 & 2 \\
\hline & & & Nam Định & 3 & 9 & 11 & 0 & 5 \\
\hline & & & Vĩnh Phúc & 2 & 3 & 7 & 1 & 1 \\
\hline & \multirow{2}{*}{$\begin{array}{l}\text { Central } \\
\text { Vietnam }\end{array}$} & North & * Nghệ An & 1 & 1 & 1 & 0 & 0 \\
\hline & & Central & Thanh Hóa & 3 & 6 & 7 & 0 & 3 \\
\hline & \multirow{3}{*}{$\begin{array}{l}\text { Southern } \\
\text { Vietnam }\end{array}$} & \multirow{3}{*}{$\begin{array}{c}\text { Mekong } \\
\text { River Delta }\end{array}$} & Cần Thơ & 3 & 5 & 7 & 0 & 5 \\
\hline & & & Đồng Tháp & 2 & 5 & 8 & 0 & 3 \\
\hline & & & Vĩnh Long & 2 & 3 & 3 & 0 & 0 \\
\hline & Total & & & 30 & 62 & 85 & 5 & 32 \\
\hline \multirow{13}{*}{ Laos } & \multirow{3}{*}{$\begin{array}{l}\text { Northern } \\
\text { Laos }\end{array}$} & \multirow{3}{*}{ North West } & $\begin{array}{l}\text { Luang } \\
\text { Prabang }\end{array}$ & 1 & 2 & 2 & 0 & 0 \\
\hline & & & Oudomxay & 2 & 8 & 11 & 1 & 1 \\
\hline & & & Xiangkhouang & 2 & 6 & 6 & 0 & 5 \\
\hline & \multirow{5}{*}{$\begin{array}{l}\text { Central } \\
\text { Laos }\end{array}$} & \multirow{5}{*}{ Central } & $\begin{array}{l}\text { Vientiane } \\
\text { Capital }\end{array}$ & 6 & 22 & 28 & 1 & 3 \\
\hline & & & Vientiane & 3 & 12 & 15 & 0 & 2 \\
\hline & & & Bolikhamxai & 2 & 3 & 3 & 0 & 2 \\
\hline & & & Khammouane & 1 & 2 & 2 & 0 & 0 \\
\hline & & & Savannakhet & 3 & 16 & 19 & 0 & 9 \\
\hline & \multirow{4}{*}{$\begin{array}{l}\text { Southern } \\
\text { Laos }\end{array}$} & \multirow{4}{*}{ South East } & Attapeu & 2 & 3 & 4 & 0 & 0 \\
\hline & & & Champasak & 1 & 6 & 10 & 0 & 1 \\
\hline & & & Salavan & 2 & 7 & 10 & 0 & 1 \\
\hline & & & Sekong & 2 & 9 & 10 & 0 & 2 \\
\hline & Total & & & 27 & 96 & 120 & 2 & 26 \\
\hline
\end{tabular}

* Provinces indicated in bold are surveyed in both the 2018 and 2020 surveys.

\subsection{Survey: Sample Processing and Detection of Foc}

Fungal isolation: The isolation of Foc TR4 from discolored pseudostem samples was conducted at the Plant Quarantine Diagnostic Centre (PQDC) in Hanoi, Vietnam, and at the Department of Agriculture and Forestry in Vientiane Capital, Laos. In the laboratory, Foc isolation was conducted as described by Dita et al. [39], García-Bastidas et al. [24] and Viljoen et al. [36]. Pseudostem samples were first surface sterilized, and primary isolations were performed by plating out $5 \mathrm{~mm}$ strands of infected vascular tissue on potato dextrose agar (PDA). After 3 days, fungal colonies suggestive of Fusarium spp. were sub-cultured onto PDA plates and incubated at $25^{\circ} \mathrm{C}$. After 7 to 10 days, pure cultures were obtained from cultures with Foc characteristic morphological features by further sub-culturing using hyphae tipping onto PDA plates and incubating as described above. The purified cultures were then stored on PDA at $-4{ }^{\circ} \mathrm{C}$ for short-term storage and in $30 \%$ glycerol at $-80{ }^{\circ} \mathrm{C}$ for long term storage.

Genomic DNA extraction: Fungal mycelium of each isolate was harvested by carefully scraping it off the PDA agar with sterile scalpel blades, and depositing it into separate, labeled, sterile $1.5 \mathrm{~mL}$ micro-centrifuge tubes. Total fungal genomic DNA of the Vietnam and Laos samples were extracted and purified using the Fair Biotech Genomic DNA 
Isolation and Purification kit (Fair Biotech, Taoyuan, Taiwan) and the PureDireX kit (BioHelix, Keelung, Taiwan), respectively. The eluted gDNA samples were then quantified using a NanoDrop ${ }^{\mathrm{TM}}$ spectrophotometer (NanoDrop, Wilmington, DE, USA), diluted to $10 \mathrm{ng} / \mu \mathrm{L}$, and stored at $-20^{\circ} \mathrm{C}$ for subsequent use.

Molecular characterization by PCR analysis: Molecular identification of Foc TR4 was conducted by a duplex PCR amplification, using a 648-bp primer specific to the detection of the translation elongation factor $1-\alpha(\mathrm{TEF} 1-\alpha)$ as an internal control gene [40] and a 463-bp Foc TR4-specific primer [39]. The PCR amplicons were electrophoresed on a 1.2\% $(w / v)$ agarose gel and visualized using an UV illuminator. Genomic DNA of a reference strain of VCG 01213/16 [33] was used as a positive control, whereas for the no template control the genomic DNA was substituted with nuclease-free water. Foc isolates for the 2018 survey were not characterized at VCG level.

\subsection{Survey: Sample Processing and Detection of Foc}

Fungal isolation: Four vascular strands of $5 \mathrm{~mm}$ each were cut from each sample and plated onto PDA supplemented with streptomycin $(4 \mathrm{mg} / \mathrm{L})$ in $90-\mathrm{mm}$-diameter Petri dishes. The Petri dishes were incubated for 7 days at $25^{\circ} \mathrm{C}$, after which the cultures were purified and single-spored. Only samples that resembled Fusarium spp. in culture were stored on carnation leaf agar (CLA) slants at $4{ }^{\circ} \mathrm{C}$ and in $30 \%$ glycerol at $-80{ }^{\circ} \mathrm{C}$ in the culture collection of the Department of Plant Pathology at Stellenbosch University, South Africa.

DNA extraction: The Fusarium spp. isolates were grown on PDA at $25^{\circ} \mathrm{C}$ for 5 days, before mycelium was harvested by scraping it off the surface with a sterile scalpel and depositing it into $2 \mathrm{~mL}$ Eppendorf tubes. The mycelia were then lyophilized in a VirTis BenchTop Pro freeze dryer (Warminster, PA, USA), and DNA extractions performed as described by González-Mendoza et al. [41]. The quality and quantity of DNA was determined with a NanoDrop Nd-1000 Spectrophotometer (Thermo Scientific, Waltham, MA, USA), and stored at $-20^{\circ} \mathrm{C}$ until use.

Molecular identification with PCR: All Fusarium sp. isolates were systematically identified using molecular markers (Supplementary Figure S1). The DNA was first PCR amplified with Foc TR4-specific primers described by Dita et al. [39] and Matthews et al. [42]. If negative, the DNA was PCR amplified with Foc Clade A-specific primers (Mostert, unpublished data) to determine if the isolates belong to VCGs 0120/15, 0121, 0122, 0126, 0129/11, 01210 and 01219 [43]. If again negative, primers specific to Foc Lineage VI was used for PCR amplification, as described by Ndayihanzamaso et al. [44] and Matthews et al. [42]. Isolates that were negative for all three PCR amplifications were subjected to PCR assays specific to Foc Lineage VII, VCG 01218 and VCG 01221 (Mostert, unpublished data). Fusarium isolates that were not amplified by any of the Foc primer sets were considered either new Foc VCGs, non-pathogenic F. oxysporum, or unknown Fusarium species.

Vegetative compatibility group testing: VCG analysis [45] was performed to confirm the identities of Foc isolates that were previously identified using molecular markers. The Foc isolates were first grown on PDA for 7 days at $25^{\circ} \mathrm{C}$, and the hyphae of actively growing cultures transferred onto minimal media (MM) supplemented with $1-3 \% \mathrm{KClO}_{3}$. These cultures were then incubated for $7-21$ days at $25{ }^{\circ} \mathrm{C}$ to generate $\mathrm{ClO}_{3}$-resistant mutants. Sectors of sparse mycelial growth colonies were considered nitrate non-utilizing (nit)mutants, and were phenotyped as nit-1, nit-3 or Nit-M mutants [45]. The VCG identities of Foc isolates from Laos and Vietnam were then determined by pairing nit-1 and nit-3 mutants with Nit-M testers of known VCGs. Isolates earlier identified as Foc TR4 using molecular markers were paired with VCGs 01213, 01216 and 01213/16, and those that amplified with Lineage VI-specific primers were tested against VCGs 0124, 0125, 0128, 01212, 01220 and 01222. The isolates that tested positive for Lineage VII were paired with VCGs 0123, 01217, 01223 and 01224. If the isolates produced amplification products specific to VCG 01218 and VCG 01221, they were paired with these testers. The unknown isolates were designated a specific VCG if their nit-mutants formed heterokaryons with 
Nit-M mutants of VCG tester strains [45]. When nit-1 and nit-3 mutants of a particular isolate failed to pair with its own Nit-M mutants, the isolate was considered heterokaryon self-incompatible. All the pairings were repeated at least once.

\section{Results}

Fusarium wilt was widely found in the northern regions of Laos and Vietnam, the central and southern regions of Laos and the southern regions of Vietnam (Figure 2). Of a total of 507 fields in which symptomatic plants were inspected and sampled during 2018 and 2020, positive identifications of Fusarium wilt have been made in 148 fields, indicating that these fields have at least one banana plant infected with Foc. Accordingly, in 29.2\% of fields with symptomatic plants, the symptoms of wilting were confirmed, using a Foc TR4-specific primer [39] (Supplementary Figure S2) and VCGs (Supplementary Figure S3) to be caused by Foc TR4. Most of the Foc TR4-infected Cavendish bananas were recorded in the northern parts of Laos and Vietnam (Figure 2, Table 1).

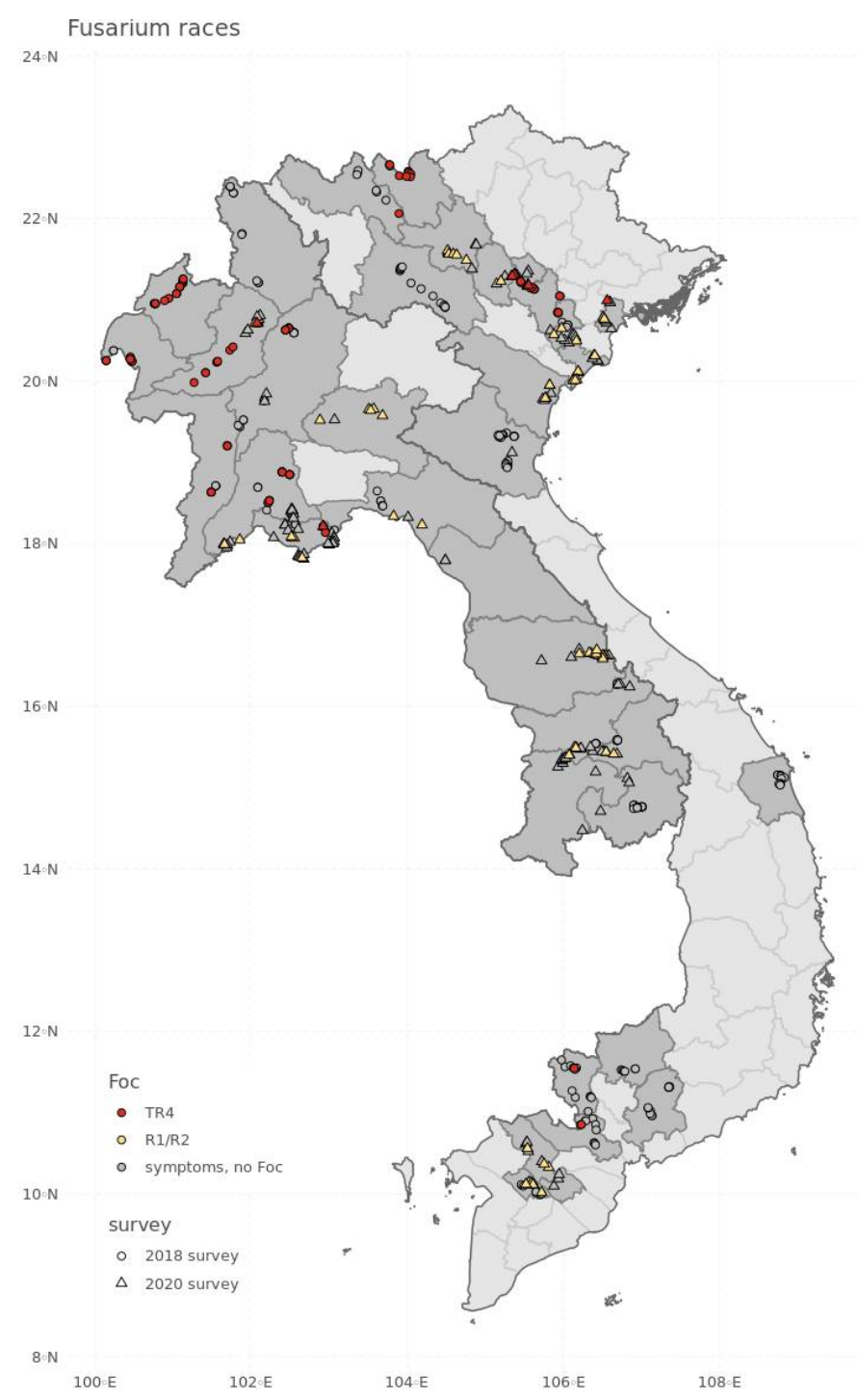

Figure 2. Observations of Fusarium oxysporum f. sp. cubense (Foc) TR4 and Foc R1/R2. Fields surveyed in 2018 are indicated as circles, whereas fields surveyed in 2020 are marked as triangles. Grey points show fields with banana plants showing the traditional symptoms of wilt, but were not identified as fusarium; red points denote sites where Foc TR4 was positively identified; yellow points indicate sites where Foc R1/R2 was positively identified. 
In Laos, a substantial number of Cavendish fields were infected with TR4 in the northwestern provinces of Bokeo (71.4\% of fields with symptomatic plants), Luang Namtha $(100 \%)$, Oudomxay (60\%), Xaignabouly (70\%) and Luang Prabang (30\%) (Table 1$)$ and the central provinces of Vientiane (59.1\%) and Vientiane Capital $(20 \%)$. None of the Cavendish fields in the southern provinces of Laos were infected with Foc TR4. In Vietnam, Foc TR4 infected Cavendish fields were observed in the northwestern provinces of Lao Cai (80\%) and Lai Chau (14.3\%) (Table 1), and in the provinces Hanoi (50\%) and Hung Yen in the Red River Delta (36.4\%). Two additional Foc TR4-infested Cavendish fields were identified in the 2020 survey in the Red River Delta region and three in the northeastern province of Phu Tho (Table 2). In the southern parts of Vietnam, two Foc TR4-infested Cavendish fields were observed in the provinces of Tay Ninh and Long An, respectively (Figure 2, Table 1).

In 2020, 'Pisang Awak' (ABB) was the banana variety most affected by Fusarium wilt. Symptomatic 'Pisang Awak' plants were collected from 76 fields, four of which also had symptomatic Cavendish plants. Symptomatic Cavendish plants were collected in an additional four fields, symptomatic 'Pisang Mas' (AA, Subgroup Sucrier) plants from two fields and symptomatic triploid BBB cooking banana from three fields in Vietnam. In Laos, symptomatic 'Pisang Awak' plants were found in 118 fields, and symptomatic Cavendish plants in only two fields.

Foc R1/R2 was recorded in all regions of Laos and Vietnam (Figure 2). In Laos, Foc R1/R2 was found in the northwestern provinces of Oudomxay (9.1\%) and Xiangkhouang $(83.3 \%)$ (Table 2), the central provinces of Vientiane Capital (10.7\%), Vientiane (13.3\%), Bolikhamxai $(66.7 \%)$ and Savannakhet $(47.4 \%)$ and the south-eastern provinces of Champasak (10\%), Salavan (10\%) and Sekong (20\%). In Vietnam, Foc R1/R2 found in the northwestern province of Yen Bai (50\%), the northeastern province of Phu Tho (45.5\%), the provinces Ha Nam (30\%), Hai Phong (20\%), Nam Dinh (45.5\%) and Vin Phuc in the Red River Delta $(14.3 \%)$, the central province Thanh Hoa $(42.9 \%)$ and the southern provinces Can Tho $(71.4 \%)$ and Dong Thap (37.5\%) in the Mekong River Delta.

'Pisang Awak' was infected by several VCGs of Foc R1/R2 (Figure 3, Table 3). In Laos, VCG 0123 was most common and was recorded in 20 fields. VCGs 0124, 01218 and 01221 were each isolated from 'Pisang Awak', each recorded in only two fields. In Vietnam, 'Pisang Awak' was infected with VCG 0124/5 in 17 fields, with VCG 01221 in seven fields, and with VCG 01218 in four fields. On two occasions, more than one Foc VCGs were identified in a single field. This included VCGs 0124 and 01218 in a 'Pisang Awak' small-holder farm in Can Tho, and VCGs 01213/16 and 0124 in a Cavendish/ 'Pisang Awak' small-holder farm in Phu Tho. Four isolates obtained from 'Pisang Awak' plants that amplified with Foc Lineage VII-specific primers did not pair with known VCG testers in this Lineage (Table 3). A single field with symptomatic 'Pisang Mas' plants was infected with VCG 0124, whereas the few symptomatic triploid BBB cooking bananas sampled were not infected by Foc. All Foc strains collected from Cavendish banana plants were identified as Foc TR4 (VCG 01213/16). Foc TR4 race was not isolated from 'Pisang Awak', 'Pisang Mas' or the triploid BBB cooking banana.

Fusarium wilt was found in all types of farms surveyed in Laos and Vietnam, including backyard gardens, small-holder farms and large-scale plantations. In both 2018 and 2020 surveys, Foc TR4 was only associated with large-scale Cavendish banana farms in Laos, whereas it was mainly recorded on small-scale Cavendish farms in Vietnam. Foc R1/R2 was collected from 'Pisang Awak' plants in Laos in 13 out of 65 backyard gardens, in eight of the 35 small-holder farms, and in five of 18 commercial plantations. In Vietnam, Foc R1/R2 was found in 18 of the 43 backyard gardens investigated, in nine of the 31 small-holder farms and in four of the six 'Pisang Awak' commercial plantations investigated.

The interviews conducted during the 2020 survey revealed that banana farmers were generally unaware of the threat posed by Fusarium wilt. Only four of the 120 farmers interviewed in Laos had heard of Fusarium wilt prior to the interview but did not know the cause of the disease. Three of these farmers could identify leaf yellowing and stem rot as symptoms. These farmers received the information from neighboring farmers. In 
Vietnam, only one of the 121 interviewed farmers knew of Fusarium wilt. Their knowledge of the disease was gained through the internet. This farmer was very well informed of Foc epidemiology. None of the farmers in Laos or Vietnam performed any pest or disease management and were unaware of biosecurity measures or quarantine regulations in their region. New planting material was mainly sourced as suckers; namely, $86.5 \%$ of interviewed farmers in Laos sourced new suckers from neighboring fields, and $10.1 \%$ from another village. In Vietnam, $94.2 \%$ of interviewed farmers sourced new suckers from neighboring fields. The remaining farmers obtained new material as tissue culture-derived plantlets.

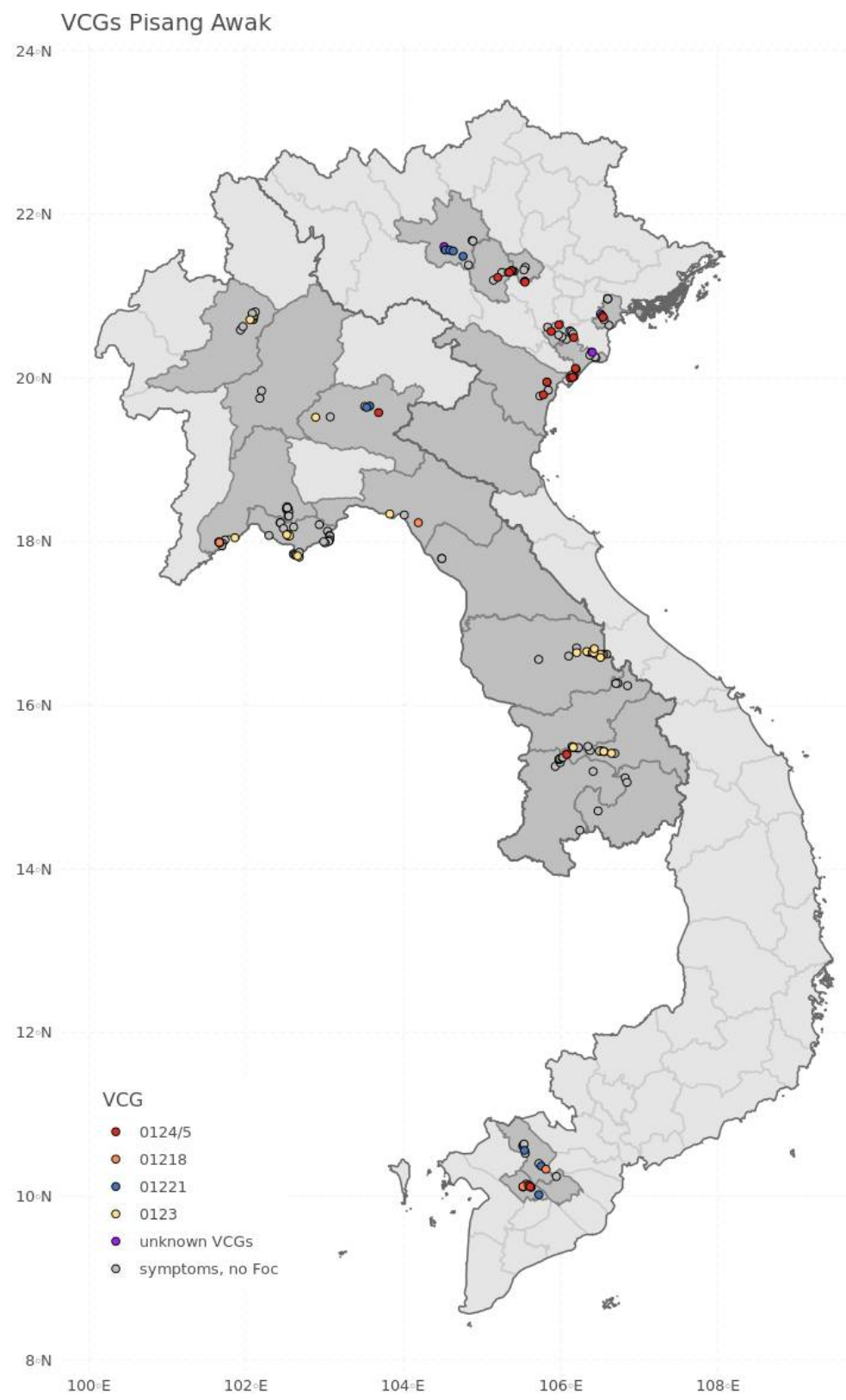

Figure 3. Observations of various VCGs associated with 'Pisang Awak'. Grey points show 'Pisang Awak' fields which showed the traditional symptoms of wilt, but were not identified as fusarium. Red points show fields where VCG 0124/5 was positively identified; yellow points where VCG 0123 was identified; blue points where VCG 01221 was identified; orange points where VCG 01218 was identified. 
Table 3. Vegetative compatibility group (VCG) identification of Fusarium oxysporum $\mathrm{f}$. sp. cubense during the 2020 survey. VCG and race identification of samples isolated from specific cultivars. The number of fields in which these VCG cultivar associations are found are indicated per province.

\begin{tabular}{|c|c|c|c|c|c|c|c|}
\hline Country & Region & Province & Banana Cultivar & $\begin{array}{l}\text { Genome } \\
\text { Group }\end{array}$ & Foc Race * & VCG & Fields \\
\hline \multirow{24}{*}{ Vietnam } & \multirow{2}{*}{ North West } & Yên Bái & 'Pisang Awak' & $\mathrm{ABB}$ & R1 & 01221 & 4 \\
\hline & & Yên Bái & 'Pisang Awak' & $\mathrm{ABB}$ & $\mathrm{R} 1 / \mathrm{R} 2$ & Unknown VCG & 1 \\
\hline & \multirow{4}{*}{ North East } & Phú Thọ & Cavendish & AAA & TR4 & $01213 / 16$ & 3 \\
\hline & & Phú Thọ & ‘Pisang Awak' & $\mathrm{ABB}$ & $\mathrm{R} 1$ & 01218 & 1 \\
\hline & & Phú Thọ & 'Pisang Awak' & $\mathrm{ABB}$ & $\mathrm{R} 1 / \mathrm{R} 2$ & $0124 / 5$ & 3 \\
\hline & & Phú Thọ & 'Pisang Awak' & $\mathrm{ABB}$ & $\mathrm{R} 1 / \mathrm{R} 2$ & 0124 & 1 \\
\hline & \multirow{9}{*}{ River Delta } & Hà Nam & 'Pisang Awak' & $\mathrm{ABB}$ & $\mathrm{R} 1 / \mathrm{R} 2$ & $0124 / 5$ & 3 \\
\hline & & Hải Phòng & Cavendish & AAA & TR4 & $01213 / 16$ & 1 \\
\hline & & Hải Phòng & 'Pisang Awak' & $\mathrm{ABB}$ & $\mathrm{R} 1 / \mathrm{R} 2$ & $0124 / 5$ & 1 \\
\hline & & Hải Phòng & 'Pisang Awak' & $\mathrm{ABB}$ & $\mathrm{R} 1 / \mathrm{R} 2$ & Unknown VCG & 1 \\
\hline & & Nam Định & 'Pisang Awak' & $\mathrm{ABB}$ & R1 & Unknown VCG & 1 \\
\hline & & Nam Định & ‘Pisang Awak' & $\mathrm{ABB}$ & $\mathrm{R} 1 / \mathrm{R} 2$ & $0124 / 5$ & 2 \\
\hline & & Nam Định & 'Pisang Awak' & $\mathrm{ABB}$ & $\mathrm{R} 1 / \mathrm{R} 2$ & 0124 & 2 \\
\hline & & Vĩnh Phúc & Cavendish & AAA & TR4 & 01213/16 & 1 \\
\hline & & Vĩnh Phúc & 'Pisang Awak' & $\mathrm{ABB}$ & $\mathrm{R} 1 / \mathrm{R} 2$ & 0124 & 1 \\
\hline & \multirow{3}{*}{$\begin{array}{l}\text { North } \\
\text { Central }\end{array}$} & Thanh Hóa & 'Pisang Awak' & $\mathrm{ABB}$ & $\mathrm{R} 1 / \mathrm{R} 2$ & $0124 / 5$ & 1 \\
\hline & & Thanh Hóa & 'Pisang Awak' & $\mathrm{ABB}$ & $\mathrm{R} 1 / \mathrm{R} 2$ & 0125 & 1 \\
\hline & & Thanh Hóa & 'Pisang Mas' & $\mathrm{AA}$ & $\mathrm{R} 1 / \mathrm{R} 2$ & 0124 & 1 \\
\hline & \multirow{6}{*}{$\begin{array}{c}\text { Mekong } \\
\text { River Delta }\end{array}$} & Cần Thơ & 'Pisang Awak' & $\mathrm{ABB}$ & R1 & 01218 & 2 \\
\hline & & Cần Thơ & 'Pisang Awak' & $\mathrm{ABB}$ & $\mathrm{R} 1$ & 01221 & 1 \\
\hline & & Cần Thơ & 'Pisang Awak' & $\mathrm{ABB}$ & $\mathrm{R} 1 / \mathrm{R} 2$ & 0124 & 2 \\
\hline & & Cần Thơ & 'Pisang Awak' & $\mathrm{ABB}$ & $\mathrm{R} 1 / \mathrm{R} 2$ & Unknown VCG & 1 \\
\hline & & Đồng Tháp & 'Pisang Awak' & $\mathrm{ABB}$ & R1 & 01218 & 1 \\
\hline & & Đồng Tháp & 'Pisang Awak' & $\mathrm{ABB}$ & $\mathrm{R} 1$ & 01221 & 2 \\
\hline \multirow{15}{*}{ Laos } & \multirow{5}{*}{ North West } & Oudomxay & Cavendish & AAA & TR4 & $01213 / 16$ & 1 \\
\hline & & Oudomxay & 'Pisang Awak' & $\mathrm{ABB}$ & $\mathrm{R} 1$ & 0123 & 1 \\
\hline & & Xiangkhouang & 'Pisang Awak' & $\mathrm{ABB}$ & $\mathrm{R} 1$ & 01221 & 2 \\
\hline & & Xiangkhouang & 'Pisang Awak' & $\mathrm{ABB}$ & $\mathrm{R} 1$ & 0123 & 2 \\
\hline & & Xiangkhouang & 'Pisang Awak' & $\mathrm{ABB}$ & $\mathrm{R} 1 / \mathrm{R} 2$ & 0124 & 1 \\
\hline & \multirow{7}{*}{ Central } & $\begin{array}{l}\text { Vientiane } \\
\text { Capital }\end{array}$ & Cavendish & AAA & TR4 & $01213 / 16$ & 1 \\
\hline & & $\begin{array}{c}\text { Vientiane } \\
\text { Capital }\end{array}$ & 'Pisang Awak' & $\mathrm{ABB}$ & $\mathrm{R} 1$ & 0123 & 3 \\
\hline & & Vientiane & 'Pisang Awak' & $\mathrm{ABB}$ & R1 & 01218 & 1 \\
\hline & & Vientiane & 'Pisang Awak' & $\mathrm{ABB}$ & R1 & 0123 & 1 \\
\hline & & Bolikhamxai & 'Pisang Awak' & $\mathrm{ABB}$ & $\mathrm{R} 1$ & 01218 & 1 \\
\hline & & Bolikhamxai & 'Pisang Awak' & $\mathrm{ABB}$ & $\mathrm{R} 1$ & 0123 & 1 \\
\hline & & Savannakhet & 'Pisang Awak' & $\mathrm{ABB}$ & $\mathrm{R} 1$ & 0123 & 9 \\
\hline & \multirow{3}{*}{ South East } & Champasak & ‘Pisang Awak' & $\mathrm{ABB}$ & $\mathrm{R} 1 / \mathrm{R} 2$ & 0124 & 1 \\
\hline & & Salavan & 'Pisang Awak' & $\mathrm{ABB}$ & $\mathrm{R} 1$ & 0123 & 1 \\
\hline & & Sekong & 'Pisang Awak' & $\mathrm{ABB}$ & R1 & 0123 & 2 \\
\hline
\end{tabular}

${ }^{*} \mathrm{R} 1, \mathrm{R} 2$ and TR4 are different races.

\section{Discussion}

Foc TR4 was first detected in Luang Namtha and the Vientiane provinces of Laos in 2017 [32] and in Hanoi, Hung Yen and Lao Cai in Vietnam in 2014 and 2015 [33]. The current study has confirmed the presence of Foc TR4 in these provinces, but also the dissemination of Foc TR4 into additional regions in both countries. In Laos, a substantial number of Foc TR4-infested Cavendish fields have now further been identified in the northwestern provinces of Bokeo, Luang Prabang, Oudomxay and Xaignabouly. In Vietnam, most TR4infested Cavendish fields were observed in the previously identified provinces of Hanoi, 
Hung Yen and Lao Cai, with additional scattered detections in the northern provinces of Lai Chai, Phu Tho, Hai Phong and Vinh Phuc and the southern provinces of Tay Ninh and Long An. It is believed that the expanding Cavendish cultivation by Chinese companies in the two countries with material sourced from potentially Foc TR4-infested plantations, without strict quarantine measures, could have led to pathogen introduction. Once introduced, local and regional trade of planting material, bunches and other plant parts, and the movement of farm equipment and laborers, could have resulted in its spread to other regions in the countries.

In Laos, Chinese private banana companies manage Cavendish plantations across the country. Between 2016 and 2017, a total of 117 Chinese companies established banana farms in Laos, covering 26,177 hectares across the country [46]. These farms were in northern (Bokeo, Luang Namtha, Oudomxay, Laung Prabang, Xaignabouly and Phongsaly), central (Vientiane, Vientiane Capital and Bolikhamxai) and southern Laos (Salavan, Champasak, Sekong and Attapeu) [47]. The number of companies has since dropped to 90 on 20,408 hectares [46], mainly due to the rise of Foc TR4 cases [47]. Bananas in affected northern regions were either replaced with other crops or production was moved to the center and south of Laos [47], potentially distributing Foc TR4 with them. Since no Foc TR4 was observed in the southern region of Laos, it can be assumed that the companies are increasingly focused on biosecurity measures to prevent the entry of the pathogen into the new production regions.

In Vietnam, Chinese private banana companies are mainly located in the North West. The occurrence of Foc TR4 in fields in the northern provinces can, however, not be directly linked to Chinese companies, as Foc TR4 was mainly detected on small-scale Cavendish farms. It is assumed that the pathogen reached these farms through local and regional movement of infected planting materials. In addition, the inoculum could also have spread widely in northern Vietnam through the Red River and its tributaries which all start in or run through infected Cavendish production zones in southern China. In China, the rapid spread of Foc TR4 was attributed to infected planting materials and the use of irrigation water [48]. Su et al. [49] and Dita et al. [9] also reported Foc spread through contaminated irrigation water or floods to be common. In Northern Vietnam, the Lao Cai province borders China, whereas the Phu Tho, Vinh Phuc, Ha Noi, Hai Phong and Hung Yen provinces are part of the Red River delta zone. The absence of Foc TR4 in the central and coastal provinces of Vietnam can possibly be explained by the limited cultivation of Cavendish bananas in these areas.

Thus far, in both Laos and Vietnam, Foc TR4 is limited to Cavendish cultivation settings, and none of the other investigated banana cultivars ('Pisang Awak', 'Pisang Mas' or the triploid BBB cooking banana) were infected with Foc TR4. This supports the hypothesis that currently Foc TR4 in the GMS is mainly spread through infected Cavendish planting material movements, and other Cavendish-based commercial and management activities, e.g., irrigation. 'Pisang Awak', a popular banana variety in Laos and Vietnam, and predominant in smallholder settings, was only infected by VCGs belonging to Foc R1/R2. The geographical distribution of VCG 0123 (R1) across Laos, and VCG 0124/5 (R1/2) throughout Vietnam, suggests that the movement of infected planting material and soil in the two countries is the most likely means of spread on smallholder settings. Grower's surveys conducted in 2020 confirmed that new banana fields are primarily established with suckers from neighboring farms. The diversity of Foc VCGs associated with 'Pisang Awak' (VCGs 0123, 0124/5, 01218 and 01221) further suggests that Fusarium wilt is well established in the region. The same VCGs were previously reported in this region, with their occurrence closely associated with the banana variety being affected [50]. Without active prevention measures, it can be expected that Foc TR4 will spread more widely in the banana-based landscapes and start infecting other Musa cultivars grown in mixed cultivar arrangements, and subsequently through local trade.

Several Fusarium isolates collected from bananas in Laos and Vietnam could not be identified as known Foc VCGs and should be further investigated. Leaf yellowing, typical 
to Fusarium wilt, can be caused by biotic and abiotic stresses other than Fusarium wilt, such as waterlogging, nutrient deficiencies and bacterial diseases [51]. Non-pathogenic F. oxysporum strains are often isolated from diseased banana material [52], which may complicate the identification process, as it cannot be distinguished from Foc based on morphological characters or multi-gene phylogenetics. Other Fusarium spp., such as F. proliferatum, F. solani and F. semitectum, are also often associated with bananas $[53,54]$. It is, therefore, important to perform pathogenicity testing in addition to molecular identification and VCG testing when studying Fusarium spp. associated with banana.

Most of the farmers interviewed during the 2020 surveys were unaware of the cause of leaf yellowing symptoms in their banana fields, and none had any disease management practices in place. The most important practice for growers is to prevent the introduction of Foc into new areas by limiting the movement of infected material, farm equipment and/or laborers. Although governmental policy and support is critical to achieve this, effective implementation can only be achieved through improved communication and extension services. An additional level of complication for farmers can come from the fact that the symptoms of leaf yellowing are not solely associated with Fusarium wilt. During the surveys conducted in this study, Foc TR4 was isolated from only $29.2 \%$ of banana fields where samples were collected, which implies that a better understanding of causes of leaf yellowing in banana fields is required. To better manage Fusarium wilt in Laos and Vietnam, especially in Cavendish plantations biosecurity practices and extension services need to be improved. Where Foc TR4 has been introduced, susceptible Cavendish cultivars could potentially be replaced with partially resistant somaclones [22,55]. However, the use of these somaclones as a standalone innovation is not a guarantee of success. Complementary management practices, such as early detection and plant eradication, the use of biocontrol agents and soil health-oriented practices, amongst others, would still be needed to better cope with Fusarium wilt in fields established with these somaclones.

Supplementary Materials: The following are available online at https:/ /www.mdpi.com/article/10 .3390/jof8010046/s1, Figure S1: Diagram illustrating characterization strategy of Fusarium oxysporum f. sp. cubense strains collected from Vietnam and Laos during the 2020 surveys, Figure S2: Amplification products of duplex PCRs using genomic DNA from pure-cultures with Fusarium oxysporum $\mathrm{f}$. $\mathrm{sp}$. cubense (Foc)-like appearance. Duplex PCRs for Foc cultures were performed using the elongation factor-1 $\alpha$ (EF-1/EF-2) primer set as internal control in combination with the TR4-specific primer FocTR4-F/FocTR4-R. Specific DNA bands for Foc TR4 (463 bp) and elongation factor $1 \alpha(648 \mathrm{bp})$ are indicated on the right. Lanes N, P and 3-24, respectively, denote negative control (water), positive control (Foc TR4 gDNA) and gDNA of assessed plant samples. Foc cultures for detecting the presence or absence of TR4 were isolated from banana plant samples obtained from plants with Fusarium wilt characteristic symptoms on farms in Laos, Figure S3: Vegetative compatibilty between representative isolations from Laos and Vietnam and Fusarium oxysporum f. sp. cubense universal VCG testers.

Author Contributions: Conceived and developed the research concept, K.C., C.H.N., S.-J.Z., T.Y.C. and G.B.; collected field data, K.C., C.H.N., T.Y.C., N.T.T. and N.T.H.; performed laboratory analysis, W.C.B. and D.M.; curated the data, T.S. and M.K.; analyzed the data, K.C., C.H.N., W.C.B., A.F.T., E.K. and T.Y.C.; interpreted results, K.C., C.H.N., W.C.B., S.-J.Z., D.M., A.F.T., W.O., E.K., T.Y.C. and G.B.; visualized the data, E.K. and T.S.; wrote the manuscript, K.C., C.H.N., W.C.B., S.-J.Z., D.M., A.F.T., E.K. and G.B.; edited the manuscript, A.V., W.O., M.D., T.S. and G.M.; mobilized the resources for the study, G.B. All authors have read and agreed to the published version of the manuscript.

Funding: This study was supported by the Food and Agriculture Organization of the United Nations (FAO) through the project "Support of Capacity development on diagnostic and surveillance system of banana Fusarium wilt disease (TR4) (TCP/RAS/3619)", and the Consultative Group on International Agricultural Research (CGIAR) Research Program on Roots, Tubers and Bananas (RTB).

Institutional Review Board Statement: Not applicable.

Informed Consent Statement: Not applicable.

Data Availability Statement: The raw data supporting the conclusions of this manuscript will be made available by the authors, without undue reservation, to any qualified researcher. 
Acknowledgments: The authors are grateful for the support of the CGIAR Research Program on Roots, Tubers and Bananas (RTB) and the CGIAR Trust Fund contributors. We also acknowledge the Plant Quarantine Diagnostic Centre (PQDC) and the Southern Plant Protection Center (SPPC) under PPD-MARD in collaboration with the Crop Production and Plant Protection Sub-Departments (CP\&PPSD), for coordinating the FAO/PPD-funded surveys in Vietnam.

Conflicts of Interest: The authors declare that the research was conducted in the absence of any commercial or financial relationships that could be construed as or result in a potential conflict of interest.

\section{References}

1. Stover, R.H.; Simmonds, N.W. Bananas, 3rd ed.; Longman: London, UK, 1987.

2. Li, C.Y.; Mostert, G.; Zuo, C.W.; Beukes, I.; Yang, Q.S.; Sheng, O.; Kuang, R.B.; Wei, Y.R.; Hu, C.H.; Rose, L.; et al. Diversity and distribution of the banana wilt pathogen Fusarium oxysporum f. sp. cubense in China. Fungal Genom. Biol. $2013,3,111$.

3. Ploetz, R.C. Management of Fusarium wilt of banana: A review with special reference to 105 tropical race 4. Crop Prot. 2015, 73, 7-15. [CrossRef]

4. Bai, T.T.; Xu, S.; Rupp, F.; Fan, H.; Yin, K.; Guo, Z.; Zhang, L.; Yang, B.; Huang, Y.; Li, Y.; et al. Temporal variations of Fusarium oxysporum f. sp. cubense tropical race 4 population in a heavily infected banana field in Southwest China. Acta Agric. Scand. Sect. B Soil Plant Sci. 2019, 69, 641-648. [CrossRef]

5. Stover, R.H. Fusarial Wilt (Panama Disease) of Banana and Other Musa Species; Commonwealth Mycological Institute: Kew, UK, 1962; p. 117.

6. Bai, T.T.; Qin, M.; Li, X.D.; Fan, H.C.; Xu, S.T.; Zeng, L.; Zheng, S.J. An additional threat to 'Cavendish' banana growers and traders: The infection of banana peduncles by Fusarium oxysporum f. sp. cubense Tropical Race 4 (Foc TR4). Plant Health Prog. 2020, 21, 312-316. [CrossRef]

7. Pittaway, P.A.; Nasir, N.; Pegg, K.G. Soil receptivity and host-pathogen dynamics in soils naturally infested with Fusarium oxysporum f. sp. cubense, the cause of Panama disease in bananas. Aust. J. Agric. Res. 1999, 50, 623-628. [CrossRef]

8. Hennessy, C.; Walduck, G.; Daly, A.; Padovan, A. Weed hosts of Fusarium oxysporum f. sp. cubense tropical race 4 in northern Australia. Australas. Plant Pathol. 2005, 34, 115-117. [CrossRef]

9. Dita, M.A.; Barquero, M.; Heck, D.; Mizubuti, E.S.; Staver, C.P. Fusarium wilt of banana: Current knowledge and epidemiology on research needs toward sustainable disease management. Front. Plant Sci. 2018, 9, 1468. [CrossRef] [PubMed]

10. Dita, M.A.; Teixeira, L.A.J.; O’Neill, W.; Pattison, A.B.; Weinert, M.P.; Li, C.Y.; Zheng, S.J.; Staver, C.; Thangavelu, R.; Viljoen, A. Current state of Fusarium wilt of banana in the subtropics. Acta Hortic. 2020, 1272, 45-56. [CrossRef]

11. Pegg, K.G.; Coates, L.M.; O’Neill, W.T.; Turner, D.W. The Epidemiology of Fusarium Wilt of Banana. Front. Plant Sci. 2019, 10, 1395. [CrossRef]

12. Buddenhagen, I.W. Understanding strain diversity in Fusarium oxysporum f. sp. cubense and history of introduction of 'tropical race $4^{\prime}$ to better manage banana production. Acta Hortic. 2009, 828, 193-204. [CrossRef]

13. Siamak, S.B.; Zheng, S. Banana Fusarium wilt (Fusarium oxysporum f. sp. cubense) control and resistance, in the context of developing wilt-resistant bananas within sustainable production systems. Hortic. Plant J. 2018, 4, 208-218. [CrossRef]

14. Ploetz, R.C.; Correll, J.C. Vegetative compatibility among races of Fusarium oxysporum f. sp. cubense. Plant Dis. 1988, 72, 325-328. [CrossRef]

15. Bentley, S.; Dale, J.L. Genetic variation among a world-wide collection of isolates of Fusarium oxysporum f. sp. cubense analysed by RAPD-PCR fingerprinting. Mycol. Res. 1995, 99, 1378-1384. [CrossRef]

16. Ploetz, R.C.; Peggy, K.G. Fusarium wilt. In Diseases of Banana, Abaca and Enset; Jones, J.R., Ed.; CABI Publishing: Wallingford, UK, 2000; pp. 143-159.

17. Viljoen, A. The status of Fusarium wilt of banana in South Africa. S. Afr. J. Sci. 2002, 98, 341-344.

18. Ploetz, R.C. Fusarium wilt of banana is caused by several pathogens referred to as Fusarium oxysporum f. sp. cubense. Phytopathology 2006, 96, 653-656. [CrossRef]

19. Aguayo, J.; Mostert, D.; Fourrier-Jeandel, C.; Cerg-Wendling, I.; Hostachy, B.; Viljoen, A.; Ioos, R. Development of a hydrolysis probe-based real-time assay for the detection of tropical strains of Fusarium oxysporum f. sp. cubense race 4. PLoS ONE 2017, 12, e0171767. [CrossRef]

20. Czislowski, E.; Fraser-Smith, S.; Zander, M.; O’Neill, W.T.; Meldrum, R.A.; Tran-Nguyen, L.T.; Batley, J.; Aitken, E.A. Investigation of the diversity of effector genes in the banana pathogen, Fusarium oxysporum f. sp. cubense, reveals evidence of horizontal gene transfer. Mol. Plant Pathol. 2018, 19, 1155-1171. [CrossRef]

21. FAOSTAT. FAO Statistical Database. 2020. Available online: http://www.fao.org/ (accessed on 23 October 2021).

22. Viljoen, A.; Ma, L.-J.; Molina, A.B. Fusarium wilt (Panama disease) and monoculture in banana production: Resurgence of a century-old disease. In Emerging Plant Diseases and Global Food Security; Ristaino, J.B., Records, A., Eds.; American Phytopathological Society: St. Paul, MN, USA, 2020; pp. 159-184. 
23. Zheng, S.-J.; García-Bastidas, F.A.; Li, X.; Zeng, L.; Bai, T.; Xu, S.; Yin, K.; Li, H.; Fu, G.; Yu, Y.; et al. New geographical insights of the latest expansion of Fusarium oxysporum f. sp. cubense tropical race 4 into the greater Mekong subregion. Front. Plant Sci. 2018, 9, 457. [CrossRef]

24. García-Bastidas, F.; Ordóñez, N.; Konkol, J.; Al-Qasim, M.; Naser, Z.; Abdelwali, M.; Salem, N.; Waalwijk, C.; Ploetz, R.C.; Kema, G.H.J. First report of Fusarium oxysporum f. sp. cubense 86 tropical race 4 associated with Panama disease of banana outside Southeast Asia. Plant Dis. 2014, 98, 694. [CrossRef]

25. García-Bastidas, F.A.; Van der Veen, A.; Nakasato-Tagami, G.; Meijer, H.J.G.; Arango-Isaza, R.E.; Kema, G.H.J. An Improved Phenotyping Protocol for Panama Disease in Banana. Front. Plant Sci. 2019, 10, 1006. [CrossRef]

26. Maymon, M.; Shpatz, U.; Harel, Y.M.; Levy, E.; Elkind, E.; Teverovsky, E.; Gofman, R.; Haberman, A.; Zemirski, R.; Nadav, E.; et al. First report of Fusarium oxysporum f. sp. cubense tropical race 4 causing Fusarium wilt of Cavendish bananas in Israel. Plant Dis. 2018, 102, 2407-2410. [CrossRef]

27. Maymon, M.; Sela, N.; Shpatz, U.; Galpaz, N.; Freeman, S. The origin and current situation of Fusarium oxysporum f. sp. cubense tropical race 4 in Israel and the Middle east. Sci. Rep. 2020, 10, 1590. [CrossRef] [PubMed]

28. Aguayo, J.; Cerf-Wendling, I.; Folscher, A.B.; Fourrier-Jeandel, C.; Ioos, R.; Mathews, M.C.; Mostert, D.; Renault, C.; Wilson, V.; Viljoen, A. First report of Fusarium oxysporum f. sp. cubense tropical race 4 (TR4) causing banana wilt in the Island of Mayotte. Plant Dis. 2021, 105, 5-13. [CrossRef] [PubMed]

29. Viljoen, A.; Mostert, D.; Chiconela, T.; Beukes, I.; Fraser, C.; Dwyer, J.; Murray, H.; Amisse, J.; Mutabuana, E.L.; Tazan, G.; et al. Occurrence and spread of the banana fungus Fusarium oxyporum f. sp. cubense TR4 in Mozambique. S. Afr. J. Sci. 2020, 116, 1-11. [CrossRef]

30. García-Bastidas, F.A.; Quintero-Vargas, J.C.; Ayala-Vasquez, M.; Schermer, T.; Seidl, M.F.; Santos-Paiva, M.; Noguera, A.M.; Aguilera-Galvez, C.; Wittenberg, A.; Hofstede, R.; et al. First report of Fusarium Wilt Tropical race 4 in Cavendish Bananas Caused by Fusarium odoratissimum in Colombia. Plant Dis. 2020, 104, 994. [CrossRef]

31. SENASA. Confirma Brote de Fusarium Raza 4 Tropical en Piura. Available online: https://www.gob.pe/institucion/senasa/ noticias / 429832-senasa-confirma-brote-de-fusarium-raza-4-tropical-en-piura (accessed on 15 April 2021).

32. Chittarath, K.; Mostert, D.; Crew, K.S.; Viljoen, A.; Kong, G.; Molina, A.B.; Thomas, J.E. First report of Fusarium oxysporum f. sp. cubense Tropical Race 4 (VCG 01213/16) associated with Cavendish bananas in Laos. Plant Dis. 2018, 102, 449. [CrossRef]

33. Hung, T.N.; Hung, N.Q.; Mostert, D.; Viljoen, A.; Chao, C.P.; Molina, A.B. First report of Fusarium wilt on Cavendish bananas, caused by Fusarium oxysporum f. sp. cubense Tropical Race 4 (VCG 01213/16) in Vietnam. Plant Dis. 2017, 102, 448. [CrossRef]

34. International Plant Protection Convection (IPPC). Detection of Fusarium oxysporum $f$. sp. cubense Tropical Race 4 in Thailand; Plant Quarantine Research Group; Plant Protection Research and Development Office; Department of Agriculture: Bangkok, Thailand, 2019.

35. Sisanonh, S. Agricultural Statistics Year Book 2019; Ministry of Agriculture and Forestry; Department of Planning and Finance: Vientiane, Laos, 2020; p. 121

36. Viljoen, A.; Mahuku, G.S.; Massawe, C.; Tendo Ssali, R.; Kimunye, J.; Mostert, G.; Ndayihanzamaso, P.; Coyne, D. Banana Diseases and Pests: Field Guide for Diagnostics and Data Collection; IITA: Ibadan, Nigeria, 2017; p. 73.

37. Hartung, C.; Lerer, A.; Anokwa, Y.; Tseng, C.; Brunette, W.; Borriello, G. Open data kit: Tools to build information services for developing regions. In Proceedings of the 4th ACM/IEEE International Conference on Information and Communication Technologies and Development-ICTD, London, UK, 13-15 December 2010.

38. R Core Team. R: A Language and Environment for Statistical Computing; R Foundation for Statistical Computing: Vienna, Austria, 2020. Available online: https:/ / www.R-project.org/ (accessed on 12 August 2021).

39. Dita, M.A.; Waalwijk, C.; Buddenhagen, I.W.; Souza, M.T.; Kema, G.H.J. A molecular diagnostic for tropical race 4 of the banana Fusarium wilt pathogen. Plant Pathol. 2010, 59, 348-357. [CrossRef]

40. O'Donnell, K.; Kistler, H.C.; Cigelnik, E.; Ploetz, R. Multiple evolutionary origins of the fungus causing Panama disease of banana: Concordant evidence from nuclear and mitochondrial gene genealogies. Proc. Natl. Acad. Sci. USA 1998, 95, 2044-2049. [CrossRef]

41. González-Mendoza, D.; Argumedo-Delira, R.; Morales-Trejo, A.; Pulido-Herrera, A.; Cervantes-Díaz, L.; Grimaldo-Juarez, O.; Alarcón, A. A rapid method for isolation of total DNA from pathogenic filamentous plant fungi. Genet. Mol. Res. 2010, 9, 162-166. [CrossRef]

42. Matthews, M.C.; Mostert, D.; Ndayihanzamaso, P.; Rose, L.J.; Viljoen, A. Quantitative detection of economically important Fusarium oxysporum f. sp. cubense strains in Africa in 56 plants, soil and water. PLoS ONE 2020, 15, e0236110. [CrossRef] [PubMed]

43. Fourie, G.; Steenkamp, E.T.; Gordon, T.R.; Viljoen, A. Evolutionary relationships among the Fusarium oxysporum f. sp. cubense vegetative compatibility groups. Appl. Environ. Microbiol. 2009, 75, 4770-4781. [CrossRef]

44. Ndayihanzamaso, P.; Karangwa, P.; Mostert, D.; Mahuku, G.; Blomme, G.; Beed, F.; Swennen, R.; Viljoen, A. The development of a multiplex PCR assay for the detection of Fusarium oxysporum f. sp. cubense lineage VI strains in East and Central Africa. Eur. J. Plant. Pathol. 2020, 158, 495-509. [CrossRef]

45. Leslie, J.F.; Summerell, B.A. The Fusarium Laboratory Manual; Blackwell Publishing Professional: Ames, IA, USA, 2006; p. 388.

46. Kang, T. Laos Sees 76\% Increase in Banana Export Value in 2019. Available online: https://laotiantimes.com/2020/02/28/laossees-76-increase-in-banana-export-value-in-2019/ (accessed on 14 August 2020). 
47. Chittarath, K. Situation of Distribution and Management of Foc TR4 in Laos; Plant Protection Center, DOA, MAF: Vientiane, Laos, 2020; pp. 2-4.

48. Xu, L.B.; Huang, B.Z.; Wei, Y.R. Production and banana R\&D in China. In Advancing Banana and Plantain RED in Asia and the Pacific, Proceedings of the First BAPNET Steering Committee Meeting Held in Los Baños, Laguna, Philippines, 1-10 October 2002; Molina, A.B., Eusebio, J.E., Roa, V.N., Van den Bergh, I., Maghuyop, M.A.G., Eds.; INIBAP: Montpellier, France, 2003; Volume 11, pp. $77-80$.

49. Su, H.J.; Hwang, S.C.; Ko, W.H. Fusarial wilt of 'Cavendish' Bananas in Taiwan. Plant Dis. 1986, 70, 814-818. [CrossRef]

50. Mostert, D.; Molina, A.B.; Daniells, J.; Fourie, G.; Hermanto, C.; Chao, C.-P.; Fabregar, E.; Sinohin, V.G.; Masdek, N.; Thangavelu, R.; et al. The distribution and host range of Fusarium oxysporum $\mathrm{f}$. sp. cubense vegetative compatibility groups in Asia. PLoS ONE 2017, 12, e0181630. [CrossRef]

51. Jones, D.R. Handbook of Diseases of Banana, Abaca and Enset; CABI: Wallingford, UK, 2018; p. 632.

52. Nel, B.; Steinberg, C.; Labuschagne, N.; Viljoen, A. Isolation and characterization of non-pathogenic Fusarium oxysporum isolates from the rhizosphere of healthy banana plants. Plant Pathol. 2006, 55, 207-216. [CrossRef]

53. Kangire, A.; Rutherford, M. Wilt-like Disorder of Bananas in Uganda. Musa Disease Factsheet No. 10; INIBAP: Montpellier, France, 2001; p. 4.

54. Maryani, N.; Sandoval-Denis, M.; Lombard, L.; Crous, P.W.; Kema, G.H.J. New endemic Fusarium species hitch-hiking with pathogenic Fusarium strains causing Panama disease in small-holder banana plots in Indonesia. Pers. Mol. Phylogeny Evol. Fungi 2019, 43, 48-69. [CrossRef]

55. Hwang, S.C.; Ko, W.H. Cavendish banana cultivars resistant to Fusarium wilt acquired through somaclonal variation. Plant Dis. 2004, 88, 580-588. [CrossRef] [PubMed] 